\title{
Is The Oil Price a Determinant of Employment in Oil Intensive Romanian
}

\section{Communities?}

\author{
Vlad-Cosmin Bulai $\uparrow$ \\ Bucharest University of Economic Studies, 2-10 Caderea Bastiliei Street, District 1, 010374, Bucharest, Romania
}

Alexandra Horobeț

Bucharest University of Economic Studies, 2-10 Caderea Bastiliei Street, District 1, 010374, Bucharest, Romania

\begin{tabular}{ll}
\hline ARTICLE INFO & ABSTRACT \\
\hline Article History & Purpose: \\
& The purpose of this study is to determine the resilience of oil intensive Romanian
\end{tabular}

Received 15 February 2020 Accepted 21 February 2020 communities to oil price fluctuations.

JEL Classifications

O13, Q32, Q35

Design/methodology/approach:

The methodology employed is based on identifying the communities with the most extensive oil extraction activities using GIS (Geographic Information System) software. We then apply a random effects panel regression model to check the significance of the oil price as a predictor of employment.

Finding:

Results indicate that the effect of oil price fluctuations is limited, with employment in the identified communities following the national trend.

Research limitations/implications:

Unfortunately, our study is hindered by data availability issues and a short time series. Nevertheless, conclusions are backed by the country's characteristics - a diversified economy, integration with refining operations, and the presence of related manufacturing and services activities.

Originality/value:

The study adds to the existing literature by focusing on a mature region with a long history of hydrocarbon extraction activities. We argue that the study of local communities in mature regions is of great importance in the context of the ongoing energy transition, particularly of those located within the European Union.

Keywords:

random effects, oil,

resource curse,

local community

\section{Introduction}

Natural resource exploitation activities have been marred by controversy, being associated with environmental degradation. Apart from environmental issues, resource wealth has the potential to generate conflict and erode the quality of institutions by encouraging rent-seeking behaviour. Economic benefits have been questionable, both at national and local levels. Large fiscal revenues and other incomes related to extractive industries tend to present the same volatility as that of the prices of the commodities exploited. Resilience to this volatility is a key issue for both nations and local communities, with the latter potentially more vulnerable to shocks. The aim of this paper is to assess the resilience of Romanian local communities in oil intensive regions to oil price volatility. Specifically, we aim to find whether the oil price is a statistically significant predictor of employment in these communities. The interest in Romania is motivated by several factors. Firstly, this is a mature hydrocarbon region and such regions have not enjoyed great interest from the literature, as scholars prefer to focus on the effects of resource booms. Secondly, operations are extensive and geographically dispersed which helps in our assessment. Thirdly, the country is part of the European Union (EU) which has recently stated the boldest environmental ambition among all major economic

${ }^{\dagger}$ Corresponding Author: Vlad-Cosmin Bulai

Email: vldbulai@yahoo.com 
powers. This is known as the Green Deal, the main goal of which is achieving climate neutrality at the EU level by 2050 (European Commission, 2019). Fossil fuels sectors active in the EU will undoubtedly be affected by these ambitions. This makes this analysis highly relevant for policymakers.

In order to provide additional context, the next section offers a short history of the oil and gas industry in Romania. We then highlight the relevant literature. The following section presents the data used and explains the methodology. We next discuss the results and finally we offer conclusions.

\subsection{The Romanian oil and gas industry - a brief history}

The history of oil and gas in Romania is a long one; dating back to before its establishment as an industry. It has been thoroughly documented by Ivănuș et al. (2008), based on which we offer only a brief overview.

The origins of petroleum's utilisation in the Romanian space are unknown, but archaeological evidence points to it having been used in ancient times for various purposes: e.g. heating, lighting, as a lubricant for wheels and axels, and for waterproofing ships. The first written documents to mention it date back to the 15 th century. Activity ramped up gradually throughout the middle ages up to the 19th century, with oil exploited manually in pits or dug wells and used for roughly the same purposes as before.

1857 is the landmark year credited with the establishment of the petroleum industry in Romania. Three achievements make it stand out: the world's first industrial-scale petroleum refinery at Ploiești, the first oil production in the world recorded statistically (275 tons), and Bucharest becoming the first city in the world lit by oil lamps. In the following years, all aspects of the industry developed including drilling and geological research. The legislative framework improved with the 1893 regulation which allowed both locals and foreigners to obtain concessions, and the 1895 Mine Law. This paved the way for foreign capital to enter the Romanian oil industry and resulted in a veritable oil boom. By 1900 Romania was the world's third largest oil producer after the US and Russia, with 250 thousand tons. Foreign presence included J.D. Rockefeller's Standard Oil (1903), but by 1905 most of the capital in the Romanian petroleum industry was German ( $\sim 64 \%)$, with only $\sim 14 \%$ Romanian.

We should also note that oil contributed to Romanian mobility before the large-scale introduction of the automobile. Oil-burning equipment was developed for locomotives in 1887 and later perfected. This allowed locomotives to burn the low quality coal (lignite) extracted locally by mixing it with oil (Turnock, 2001).

The exploitation of natural gas began later, after it was accidentally discovered at Sărmășele (Transylvania) in 1908. This gave birth to the Romanian chemical industry with the use of the gas as a feedstock for nitrogen fertilizers (1917) and carbon black (1935). The latter is primarily used in the production of tires.

The Romanian petroleum industry declined in the aftermath of the Second World War, as much of the equipment was plundered by Soviet forces or used to pay war reparations to Moscow. It recovered and reached its peak during the communist regime, with connected industries, such as manufacturing of drilling equipment, also developing significantly. After 1990, the decline mirrored that of the rest of the economy with some stabilization and growth after 2000.

Despite being a top exporter of tools and equipment for the petroleum industry and participating in various international projects, the actual competitiveness of the industry during the communist era is hard to determine in the absence of a market economy along the entire value chain. As with the rest of the Romanian industry, the petroleum and related manufacturing sectors found themselves with outdated equipment and processes in need of "retechnologisation". Nevertheless, today the remaining facilities have benefited from investments and have proven resilient to the current low oil price environment. Many are still concentrated around the old oil-rich regions, notably Ploiești. Transylvania is still a key natural gas producing region and considerable resources have been identified in the Black Sea.

The purpose of this section has been to point out the existence of a range of connected industries and services that were developed over a long time span. We expect this to be beneficial for the resilience of the industry in Romania and to mitigate at least partially the negative effects of oil price volatility. Moreover, our analysis is focused on the most oil intensive communities. The results do not reflect the impact at the national level since operations are highly geographically dispersed, with some offshore in the Black Sea. Gas producing regions are also excluded from the analysis for reasons which will be detailed in a later section.

\section{Literature Review}

The controversial nature of the extractive sector is reflected in the academic literature, much of which portrays the availability of large volumes of natural resources as a curse. This is based in part on the "Dutch disease phenomenon" - the observation that a booming tradable sector has a negative impact on other tradable sectors. The name is connected with the discovery of the giant Groningen natural gas field in the Netherlands. The negative impact is explained by the movement of production factors to the booming sector, thus depriving the others of resources, and the inflationary effect of the positive income shock which affects the competitiveness of the other tradable sectors (Corden \& Neary, 1982). The theory was backed by empirical evidence of a negative correlation between resource abundance and economic growth (Sachs \& Warner, 1997), which was later criticised for failing to distinguish between resource abundance and dependence (Brunnschweiler \& Bulte, 2008; van der Ploeg \& Poelhekke, 2010). Nevertheless, the volatility of resource revenues resulting from that of commodity prices has been identified as one of the main 
determinants of the poor economic performance of resource dependent countries, with the effect mitigated by the presence of developed financial institutions (van der Ploeg \& Poelhekke, 2009).

Other explanations for the poor performance of resource dependent economies have been suggested. These include a propensity for rent-seeking behaviour and corruption, as evidenced in the case of Brazil (Caselli \& Michaels, 2013), and conflict generation (Lujala, Ketil Rod \& Thieme, 2007). This paper is concerned exclusively with the effects of volatility at the local level, but the potential for conflict and corruption in communities where resources are extracted may motivate future research. The reason we restrict our analysis to the local level is the fact that while Romania has extensive hydrocarbon exploitation operations, the country is at this time a net importer of crude oil and natural gas. It is in no way resource dependent and one would be hard pressed to classify it as resource abundant even factoring in newly discovered natural gas deposits in the Black Sea. This does not mean that volatility cannot manifest negative effects at the local level. Gramling \& Freudenburg (1990) found the boom and bust oil price cycle to be responsible for the boom and bust of two oil dependent local economies in Louisiana. They made the important assertion that cases of extreme volatility may be impossible for communities to adapt to or prepare for.

\section{Data, Methodology and Empirical Results}

The assessment of the level of activity in terms of hydrocarbon extraction is based on the number of wells drilled between 1970 and 2018, with more wells in a given LAU (Local Administrative Unit) indicating a greater hydrocarbon intensity. The LAU is the European classification for the smallest administrative units, typically municipalities, towns and communes. Well location data was collected from Wood Mackenzie. Geographic Information System (GIS) software (QGIS) is used to determine the number of wells corresponding to each LAU. The map data containing all LAUs comes from the National Zoning and Real Estate Publicity Agency (ANCPI). The distribution of wells is shown in figure 1 .

\section{Figure 1: Distribution of oil and gas wells}

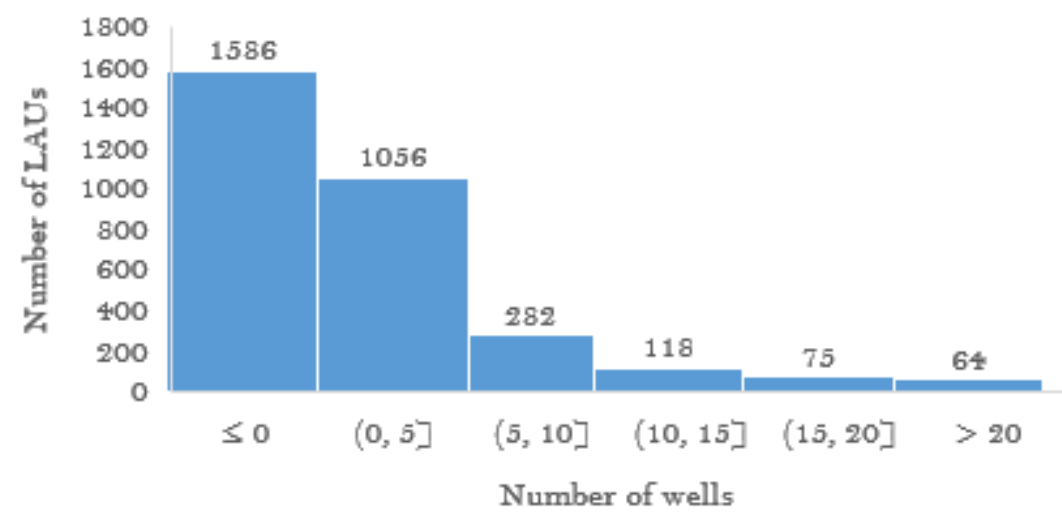

Source: Authors' calculations based on Wood Mackenzie data

We restrict our analysis to oil extraction activities for two reasons. The first is the fact that natural gas prices have been deregulated only recently. In the past, regulated prices were increased by the government with the goal of reaching the import price for Russian natural gas, according to a calendar agreed with the International Monetary Fund. In this context, local producers would be incentivised to increase production as much as possible. The second is the level of government ownership. Currently around half of the country's natural gas is extracted by Romgaz, a company in which the government has a $70 \%$ stake. A state-owned company may find it difficult to scale back its activities even in the context of a depressed market environment. This is because the government may have other objectives of a social or security nature, apart from profit maximisation.

Oil is extracted almost entirely by OMV Petrom, a subsidiary of Austrian OMV Group. The company was privatised in 2004, which is why we restrict our analysis to the 2004-2018 period. Some of the company's oil fields also produce natural gas, making a full separation between oil and gas areas impossible. Our identification strategy consists of correlating a geological map of Europe provided by the US Geological Survey (Pawlewicz, Steinshouer \& Gautier, 2002) with the well location data. The map (figure 2) shows that oil fields are concentrated in the south, west and east. The centre (Transylvania) is exclusively gas producing and is thus excluded from the analysis. The selected LAUs are presented in figure 3. The oil rich LAUs are defined as those with more than 30 wells present, with the choice informed by the distribution presented in figure 1 . Since there may be spillovers to adjacent communities, these are also included in the analysis and are identified using the same GIS software and map data. There are 117 LAUs in total. 
Figure 2: Oil and gas fields

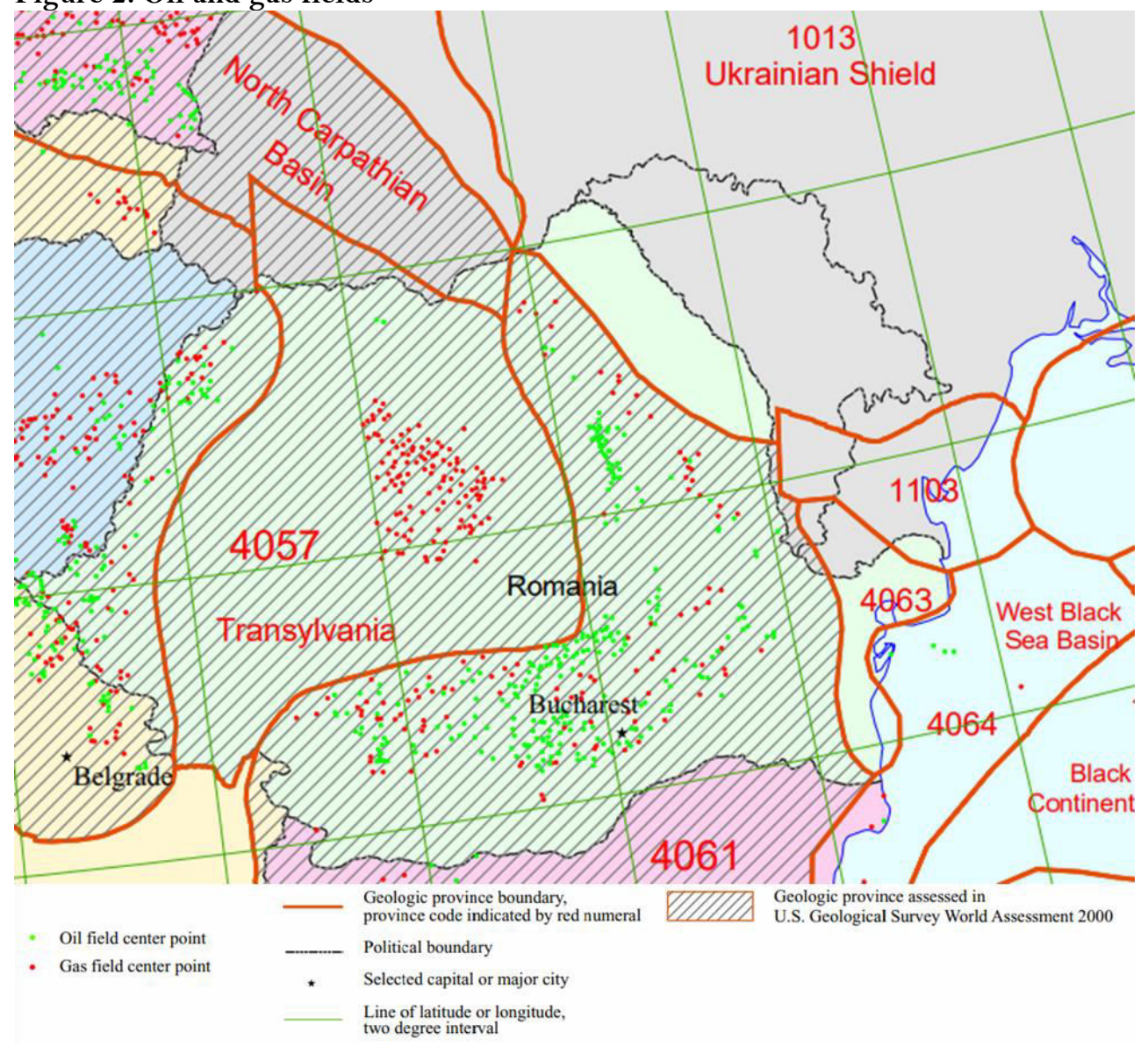

Source: Part of larger map provided by Pawlewicz, Steinshouer \& Gautier (2002)

\section{Figure 3: Oil intensive LAUs}

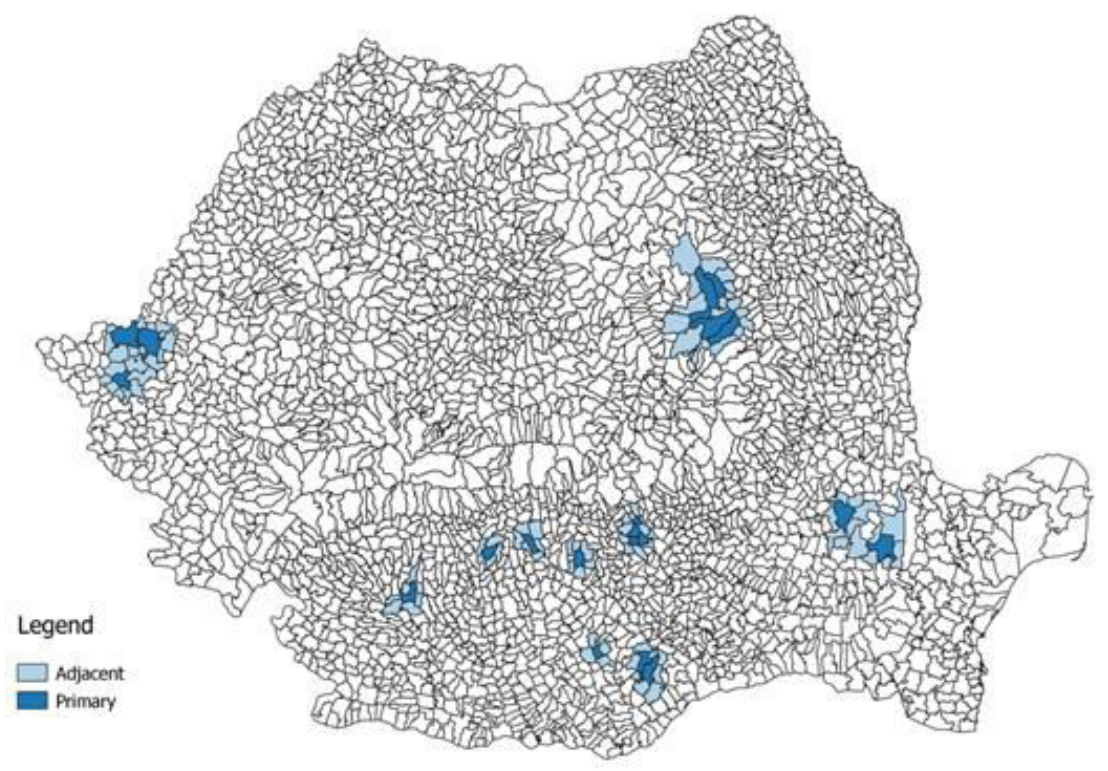

Source: Authors' calculations

Fixed effects panel regression models have been used extensively in the literature to study social and economic outcomes across resource rich local communities (for example by Drew, Dollery \& Blackwell, 2018). This is an attractive approach since it uses dummy variables to control for the particularities of each cross sectional unit. However, Bell \& Jones (2015) argue that random effects models are superior due to their greater flexibility in 
allowing for the explicit modelling of these particularities. Indeed, in our case, the LAUs of interest are geographically concentrated, but the concentrations are located in different parts of the country. Furthermore, these are comprised of 3 municipalities, 10 towns and 104 communes; 17 are in close proximity (30 km radius) to large urban centres (population over 300 thousand); 20 are primary LAUs and the rest are adjacent. An overview of some of these parameters is provided in figure 4 .

\section{Figure 4: Oil intensive LAUs location and proximity to urban centres}

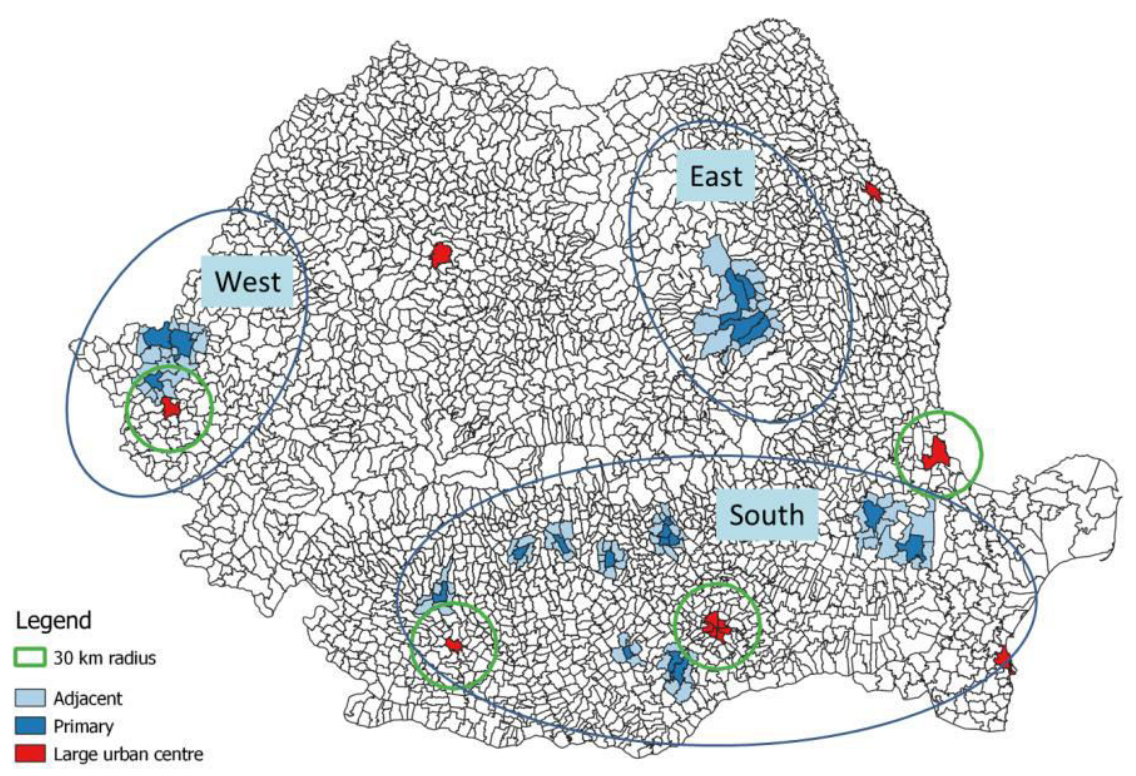

Source: Authors' calculations

The time-invariant parameters identified above are modelled as dummy variables in equation 1. Apart from these, we add two extra independent variables: the national employment from the National Institute of Statistics and the oil price (Brent blend) from the BP Statistical Review of World Energy (BP, 2019). The oil price is lagged by one period based on the logic that price movements will start producing effects after a certain period. The rationale behind using the national employment is to account for countrywide effects such as the 2008 financial crisis. The variable of interest is the oil price as we aim to find whether it is a significant determinant of employment in the selected LAUs after accounting for all the other potential determinants. Variables are introduced in logarithm form.

$$
E M P_{i t}=\alpha+O I L_{t-1}+E M P T_{t}+M_{i}+T_{i}+W_{i}+E_{i}+P_{i}+U_{i}+\varepsilon_{i t}
$$

Where the subscript $i t$ represents LAU $i$ and time $t$. EMP represents the number of employees for each LAU and each period. Data come from the National Institute of Statistics. For one LAU two values were missing and we estimated those through linear interpolation in order to obtain a balanced panel. OIL and EMPT are the lagged oil price and national employment given subscript $t$ as they only vary across time. M, T, W, E, P, and U are dummy variables pertaining to each LAU. These are time-invariant and are given subscript $i$ only. The dummy variables are coded in the above-mentioned order, as follows: 1 if the LAU is a municipality, town, located in the west, east, is primary, is in proximity to an urban centre; zero otherwise. $\boldsymbol{\varepsilon}_{\boldsymbol{i}}$ is the error term comprised of the LAU-specific (crosssectional) and the combined cross-sectional and time series error components. $\boldsymbol{\alpha}$ is the intercept.

The model was implemented in Matlab, using the Panel Data Toolbox developed by Álvarez, Barbero \& Zofío (2017). Results are presented in table 1. The coefficients have the expected signs and the oil price is significant, albeit only at the $10 \%$ level. Of note is the lack of significance for the primary dummy, suggesting a lack of spillover effects. The east and urban proximity dummies are also not statistically significant. Unfortunately the $\mathrm{R}$ squared value is only 0.54 which would indicate that the model suffers from omitted variable bias. We also ran a fixed effects model with only the oil and national employment variables. The coefficients and levels of significance were similar, but the $\mathrm{R}$ squared value was much lower at around 0.1. The fixed effects approach is no cure for the lack of data.

Table 1: Panel model results (2004-2018 period)

\begin{tabular}{|c|c|c|c|}
\hline Variable & Expected relationship & Coefficient & Standard error \\
\hline OIL & Positive & $0.0327^{*}$ & 0.0173 \\
\hline EMPT & Positive & $0.6968^{* * *}$ & 0.1405 \\
\hline M & Positive & $3.4356^{* * *}$ & 0.7169 \\
\hline
\end{tabular}




\begin{tabular}{|c|c|c|c|}
\hline & (urban areas may be more economically diversified) & & 0.4012 \\
\hline $\mathrm{T}$ & $\begin{array}{c}\text { Positive } \\
\text { (same as above) }\end{array}$ & $1.9092^{* * *}$ & 0.3000 \\
\hline $\mathrm{W}$ & $\begin{array}{c}\text { Positive } \\
\text { (the western region is typically more developed) }\end{array}$ & $1.0796^{* * *}$ & 0.3003 \\
\hline $\mathrm{E}$ & $\begin{array}{c}\text { Negative/positive } \\
\text { (the eastern region is typically less developed, but the basis } \\
\text { for comparison is the south which also contains less } \\
\text { developed areas) }\end{array}$ & 0.1749 & 0.3003 \\
\hline $\mathrm{P}$ & Positive & 0.3917 & 0.3346 \\
\hline $\mathrm{U}$ & Positive & $-5.6203^{* * *}$ & 2.1784 \\
\hline$\alpha$ & & & 0.0439 \\
\hline
\end{tabular}

Note: $*$ p value $<10 \%$; $* * *$ p value $<1 \%$

Source: Authors' calculations

Since the time series start in 2004, the sample includes the 2008-2009 financial crisis, which might impact our findings. Figure 5 shows that the oil price and national employment have followed broadly similar trajectories before and during the crisis. These began to diverge significantly with the oil price rising rapidly and then collapsing in 2015, while employment grew steadily throughout the period. It would be useful to see whether or not this collapse had an effect on employment in the selected LAUs. To this end, we run the model on a restricted sample beginning in 2011. Results are presented in table 2.

Figure 5: Lagged oil price and national employment

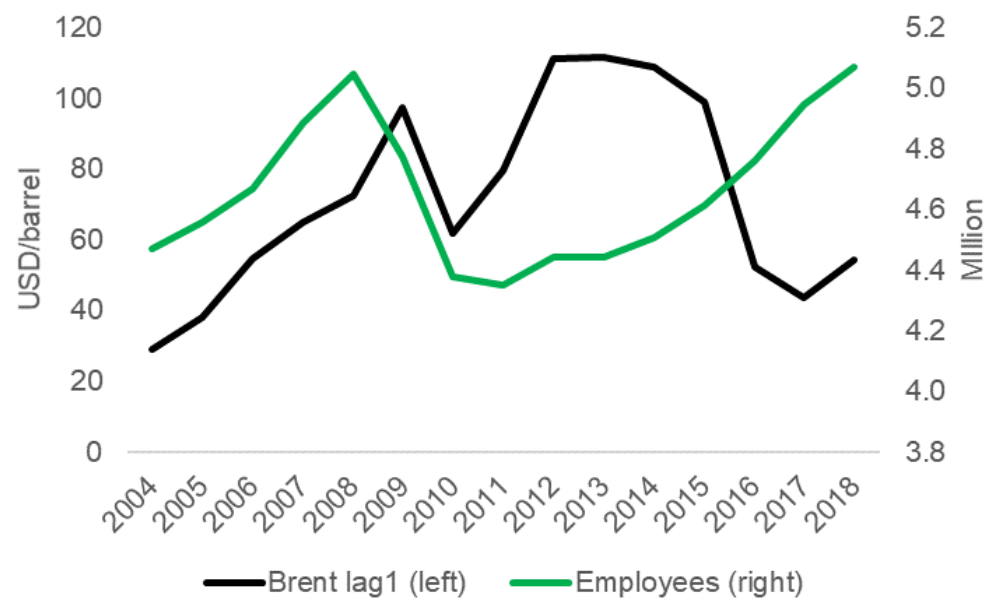

Source: Authors' calculations

Table 2: Panel model results (2011-2018 period)

\begin{tabular}{|c|c|c|}
\hline Variable & Coefficient & Standard error \\
\hline OIL & -0.0221 & 0.0297 \\
\hline EMPT & $0.3606^{*}$ & 0.2084 \\
\hline $\mathrm{M}$ & $3.2858^{* * *}$ & 0.7190 \\
\hline $\mathrm{T}$ & $1.8857^{* * *}$ & 0.4023 \\
\hline $\mathrm{W}$ & $1.3307^{*} * *$ & 0.3009 \\
\hline $\mathrm{E}$ & 0.0749 & 0.3012 \\
\hline $\mathrm{P}$ & 0.3407 & 0.3011 \\
\hline $\mathrm{U}$ & -0.0137 & 0.3355 \\
\hline$\alpha$ & -0.2264 & 3.3094 \\
\hline
\end{tabular}

Note: *p value $<10 \%$; *** p value $<1 \%$

Source: Authors' calculations

The oil price coefficient turns negative and loses its significance. National employment, type of LAU and western location are still significant. The $\mathrm{R}$ squared value increases slightly to 0.56 . The conclusion we can draw from this is 
that if there is an impact from the oil price, it is negligible at best. This does not mean that these communities are not at risk. Boom and bust cycles have been a staple of the oil industry for more than a century and the question for both companies and governments has been how to cope with this volatility. In light of the ongoing energy transition, the question should now become what happens when the resource loses its value completely? Oil has uses other than as a fuel source, such as a raw material for lubricants and various chemicals, but others may become useless. The low quality coal used in power generation is one such resource. Given mounting environmental pressure in Europe and throughout the world, this may occur sooner rather than later. Moreover, the geographical concentration of the resource makes local communities particularly vulnerable. Future research should concentrate on this area as a matter of urgency.

\section{Conclusion}

The purpose of this paper has been to assess the resilience of oil intensive Romanian local communities to the oil price. Specifically, we applied a random effects panel regression model to find whether or not the oil price is a statistically significant predictor of employment in these communities. We found that its impact is negligible or non-existent, but our model is limited by short time series and suffers from omitted variable bias due to data availability issues. Despite these limitations, the results are in line with the country's characteristics: a long history of hydrocarbon operations and the presence of related industries and services (e.g. refineries, equipment manufacturing). Nevertheless, extractive operations are faced with increasing environmental pressure, particularly those located in the EU. The energy transition is ongoing and will affect the entire energy industry. As noted previously, policymakers should not be lulled into a false sense of security since resilience to commodity cycles does not necessarily translate into resilience to a complete loss of value.

\section{References}

Álvarez, I. C., Barbero, J., \& Zofío, J. L. (2017). A Panel Data Toolbox for MATLAB. Journal of Statistical Software, 76(i06).

Bell, A., \& Jones, K. (2015). Explaining fixed effects: Random effects modeling of time-series cross-sectional and panel data. Political Science Research and Methods, 3(1), 133-153.

BP (2019). BP Statistical Review of World Energy June 2019. Retrieved from https://www.bp.com/en/global/corporate/energyeconomics/statistical-review-of-world-energy.html.

Brunnschweiler, C. N., \& Bulte, E. H. (2008). The resource curse revisited and revised: A tale of paradoxes and red herrings. Journal of environmental economics and management, 55(3), 248-264.

Caselli, F., \& Michaels, G. (2013). Do oil windfalls improve living standards? Evidence from Brazil. American Economic Journal: Applied Economics, 5(1), 208-38.

Corden, W. M., \& Neary, J. P. (1982). Booming sector and de-industrialisation in a small open economy. The economic journal, 92(368), 825-848.

Drew, J., Dollery, B. E., \& Blackwell, B. D. (2018). A square deal? Mining costs, mining royalties and local government in New South Wales, Australia. Resources Policy, 55, 113-122.

European Commission. (2019). The European Green Deal. Brussels. COM/2019/640 final

Gramling, R., \& Freudenburg, W. R. (1990). A Closer Look at "Local Control": Communities, Commodities, and the Collapse of the Coast 1. Rural Sociology, 55(4), 541-558.

Ivănuș, G., Ștefănescu, I. Ș., Antonescu, N. N., Mocuța, Ș. T., Coloja, M. P. (2008). Industria de petrol și gaze din România: tradiție și perspective. Bucuresti: Editura AGIR.

Lujala, P., Ketil Rod, J., \& Thieme, N. (2007). Fighting over oil: Introducing a new dataset. Conflict Management and Peace Science, 24(3), 239-256.

Pawlewicz, M.J., Steinshouer, D.W., Gautier, D.L. (2002). Map showing geology, oil and gas fields, and geologic provinces of Europe including Turkey: U.S. Geological Survey Open-File Report 97-470-I, 14 p., https://doi.org/10.3133/ofr97470I.

Sachs, J. D., \& Warner, A. M. (1997). Fundamental sources of long-run growth. The American economic review, 87(2), $184-188$.

Turnock, D. (2001). Railways and economic development in Romania before 1918. Journal of Transport Geography, 9(2), 137-150.

Van der Ploeg, F., \& Poelhekke, S. (2009). Volatility and the natural resource curse. Oxford economic papers, 61(4), 727-760.

Van der Ploeg, F., \& Poelhekke, S. (2010). The pungent smell of "red herrings": Subsoil assets, rents, volatility and the resource curse. Journal of Environmental Economics and Management, 60(1), 44-55. 